\title{
MODERN TRENDS IN DEMOGRAPHIC DEVELOPMENT OF SOCIETY: FINANCIAL ASPECT
}

\section{Saida Kuizheva}

Maykop State Technological University, Maykop, Russian Federation

\section{Lyudmila Prigoda}

Maykop State Technological University, Maykop, Russian Federation

OMESTE

JEL Category: J11

\begin{abstract}
The article considers modern demographic trends, analyzes the forecast scenarios of the development of the world community, taking into account the aging of the population, and justifies the need to search for new tools and sources of pension provision for citizens. A developed pension system is evidence of a high level of development of society. The maximum coverage and a decent replacement rate are evidence of the socialization of social institutions, the enhancement of the value of a citizen's life, carry humanistic ideas of ensuring a decent standard of living for the least protected social strata. However, from the economic point of view, the ideas of humanism and universal prosperity have a high price. The effectiveness of pension savings depends on many factors and the dynamics of the development of pension systems are not always unambiguous. Modern pension systems are in a disequilibrium state: most developed and developing countries are already experiencing problems with balancing the pension system or will experience pension budget deficit in the mid-term. The problems of forming pension savings are objective. The world passes through the stage of population transition, which is expressed in the reduction of population growth with the simultaneous lengthening of life expectancy. This increases the burden on pension funds, increases the age-dependent ratio of financial systems. The research hypothesis is that it is impossible to achieve a balance of the pension system while maintaining a sufficient level of pension provision through parametric reform - a paradigmatic restructuring of the pension accumulation architecture with the use of advanced financial tools is necessary. The toolmethodical apparatus, which allows achieving the reliability of conclusions and recommendations, is provided by wide application of general scientific theoretical (comparative analysis, induction, deduction, generalization, synthesis) and practical (graphical and tabular interpretation) methods of cognition. Elements of econometrics and socioeconomic modeling were used to determine demographic trends. The institutional analysis was used in the study of parametric characteristics of pension systems. To study the investment paradigm the approaches of neoclassical and modern portfolio theories and longrange forecasting were used.
\end{abstract}

Address of the corresponding author:

Lydmila Prigoda

莑=Iv_prigoda@mail.ru
Keywords: $\quad$ society aging, budget expenditures, pension payments, demographic situation, the age structure of society. 


\section{INTRODUCTION}

Demographic indicators are important for the development of a socio-economic strategy of any state. Analysis of the demographic situation in developed countries in recent years indicates a demographic crisis caused by the negative dynamics of natural reproduction of the indigenous population. The result of this trend is the problem of aging of the able-bodied population, which makes states to work out an optimal demographic policy aimed, first, at increasing the birth rate.

Russia belongs to the group of countries with a type of population reproduction that is characterized by low birth rates, high death rates, and negative natural growth. One of the main reasons for this situation is the dysfunctional consequences of social transformations in postSoviet countries. It should be noted that over the past 18 years, during the period from 2000 to 2018, positive changes have taken place in the country - birth rate is gradually beginning to increase, and the death rate is falling. But, in general, the death rate remains high in most regions with negative rates of natural increase.

As a result of demographic problems, low social security of people of the third age is observed. A developed pension system is evidence of a high level of development of society. The maximum coverage and a decent replacement rate are evidence of the socialization of the institutions of society, the enhancement of the value of a citizen's life, carry humanistic ideas of ensuring a decent standard of living for the least protected social strata.

However, from the economic point of view, the ideas of humanism and universal prosperity have a high price. The effectiveness of pension savings depends on a number of factors and the dynamics of the development of pension systems are not always unambiguous. Modern pension systems are in a disequilibrium state: most developed and developing countries are already experiencing problems with balancing the pension system or will experience a pension budget deficit in the midterm.

The current imbalance in the pension system of the Russian Federation is of an objective nature, consisting in universal demographic trends in the development of society, including population transition, changing behavioral patterns replacing the principle of solidarity of generations with social individualism, and reducing formal corporate employment. The situation is exacerbated by opportunistic decisions to increase the expenses of the Pension Fund of Russia (PFR), unbalancing the distribution component. The combination of these factors hinders the possibility of preserving the pension system of the Russian Federation in an unchanged form, and parametric changes have limited effectiveness and are not able to prevent the default of the distribution component, which implies a shift in emphasis to a contributory principle.

\section{ANALYSIS}

The aging of society is the main reason for the negative trends in pension provision of the population (Figure 1). Budget expenditures for an elderly person are 8 times higher than those for a working-age citizen and 25 times than that for a child. Accordingly, the movement of $10 \%$ of the population from the able-bodied category to the senior age increases public spending by $4.7 \%$ of GDP, taking into account that other conditions are equal. (Gokhale \& Smetters, 2006)

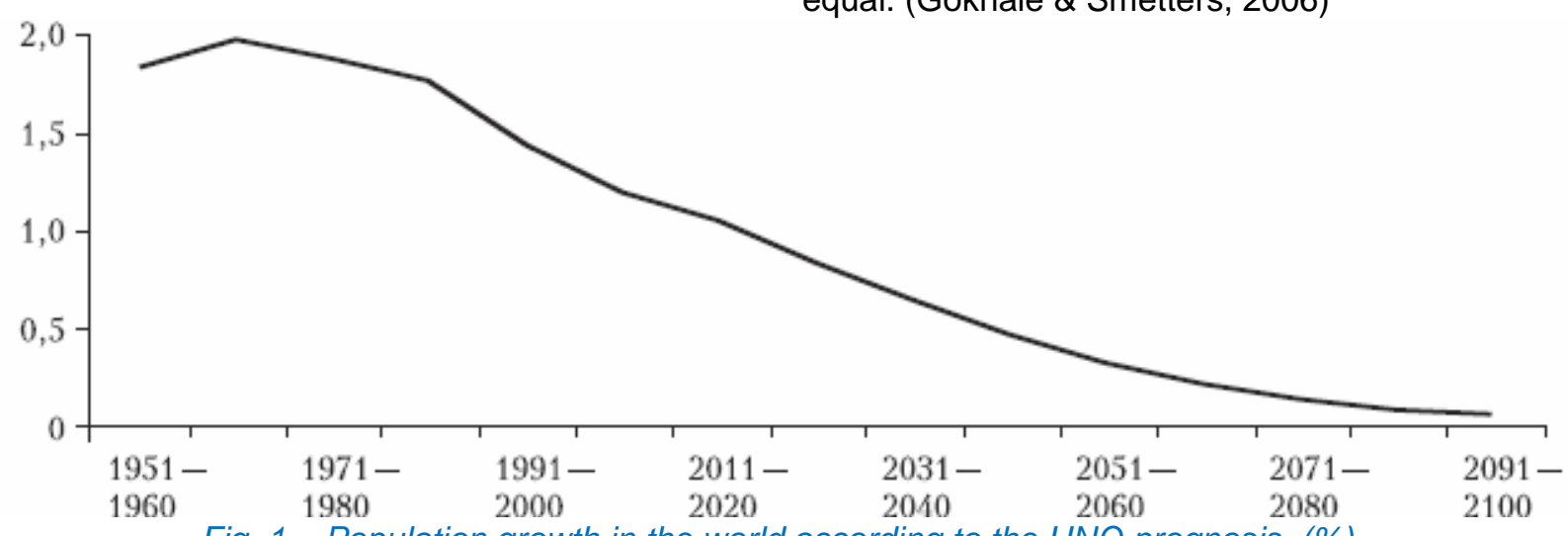

Fig. 1 - Population growth in the world according to the UNO prognosis (\%)

Source: (Gokhale \& Smetters, 2006) 
There is some agreement on the prospects and trends in the development of the demographic situation. Thus, according to the "benchmark scenario of the Working Group on Aging" (a cautious scenario that takes into account the combined impact of aging, potential improvements in health status and the impact of changes in

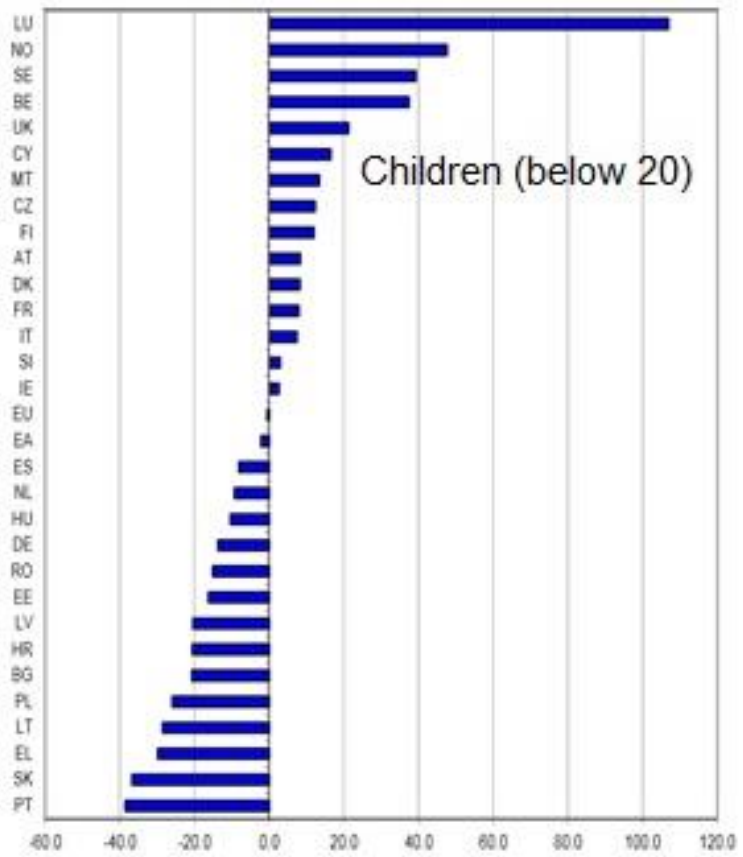

Fig. 2 - Projected change of main population groups (in \% change over the period 2013-2060)
Despite the clear prospects for the development of world demography (Figure 2), there is a fundamental difference in assessing the state and prospects of the Russian pension segment between the international community and the Russian government represented by the Ministry of Labor and the Ministry of Economy. The reason lies in different estimates of life expectancy, and, accordingly, the structure of the population.

Even domestic short-term forecasts are rather pessimistic: "gradual increase in the expected period of labor pension payment used to calculate the insurance part of the labor pension from 19 years (228 months) in 2013 to 21 years (252 months) in 2015, from an increase in the average life expectancy of a labor pension recipient". At the same time, there is no obvious way out of the situation, as evidenced by the vague wording: "It is proposed to determine the duration of the expected payment period annually according to the order stated by the Government of the Russian Federation" (Mintrud Rossii, 2012), that is,
Source: (European Commision, 2015)

national income), in the EU countries, on average, public health expenditure is forecasted to increase by $1,5 \%$ of GDP (from $6.7 \%$ in 2007 to $8.2 \%$ in 2060), while for some countries this growth ranges from less than 1\% of GDP for Cyprus, Bulgaria and Sweden to more than 3\% of GDP for Malta (European Commision, 2015).

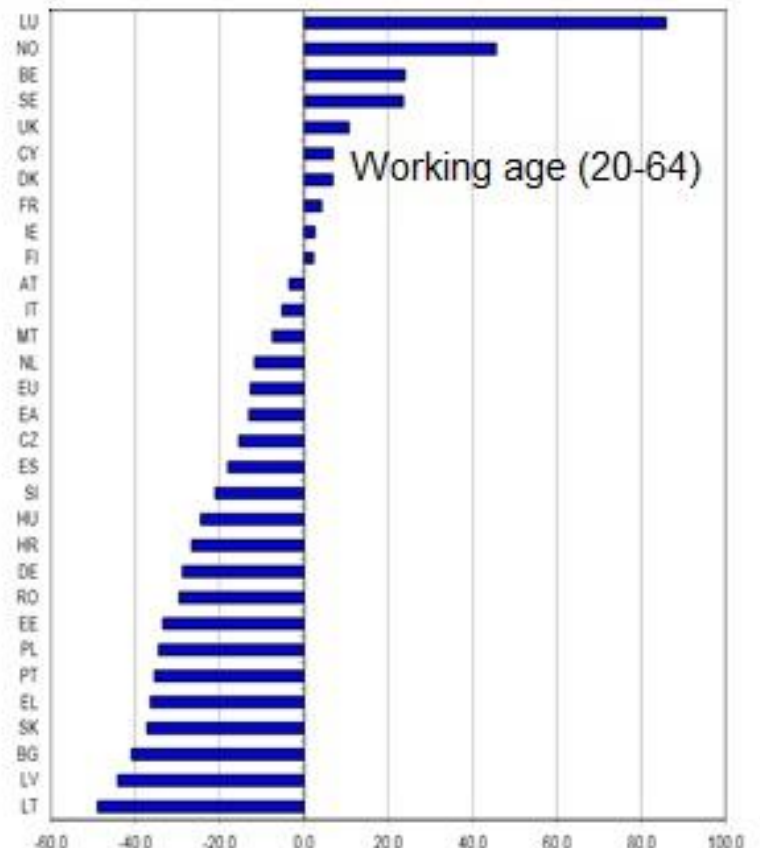

mechanisms and tools are not available yet, and it is still not clear what they will be like.

According to international estimates, the number of younger age groups in the Russian Federation will remain almost unchanged, while the number of the older one will grow in the next 50 years with the decrease in the working-age population. Between 2050 and 2060 the number of the senior group will reach a maximum of 39 million people (compared with the current 25 million), and the working-age group, on the contrary, will reach a minimum: 64 million versus current 96 million.

The growth of the total number of pensioners aggravates the problem. Demographers promise that by 2030 the number of workers and pensioners (if the current retirement age is preserved) in Russia will be approximately equal then it will be possible to forget not only about funded but about ordinary insurance pensions. Russia is already on the list of the ten countries with the biggest risks due to population aging, compiled by Bloomberg agency (Figure 3). 


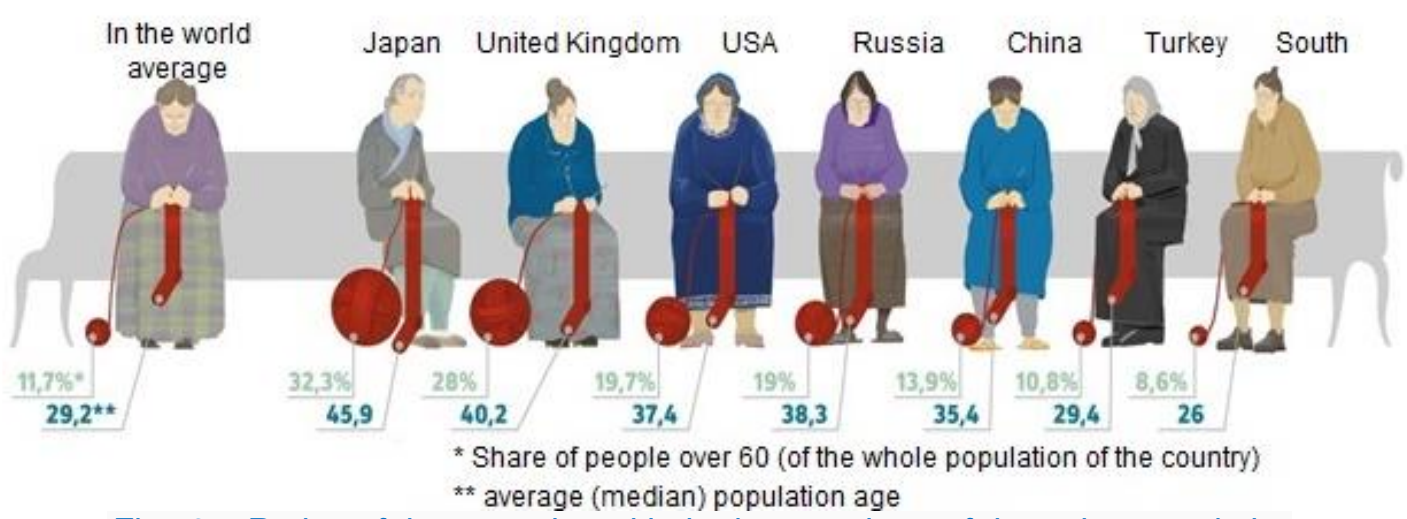

Fig. 3 - Rating of the countries with the largest share of the aging population

Source: (opensii.info, 2010)

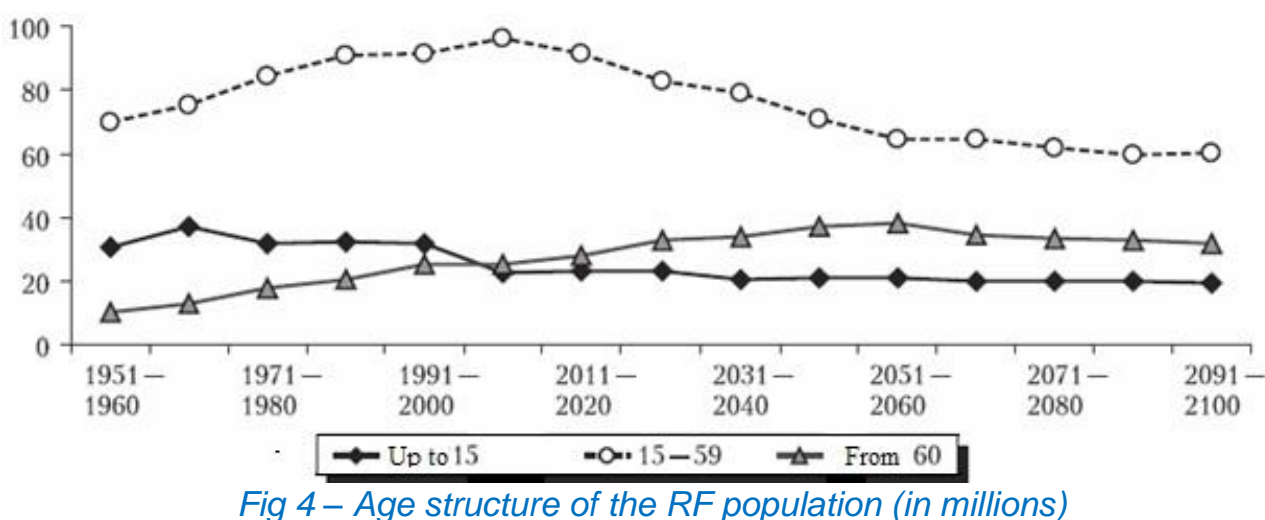

Source: (UN, 2011)

The expert council under the president points out that: "The emerging trends in the decline in death rate allow to suggest that Russia may enter the second stage of population aging - "aging from above", when the number of older age groups is growing not only due to narrowing the base of the age pyramid but due to expanding its top as a result of the growth of life expectancy in elderly age groups and the increase in the period of receiving a pension (Figure 4). This stage of aging is characterized by a significant change in the age structure of the "third" age population, its own aging. As a result, the priorities of the policy of securing the life of pensioners can change significantly due to a change in the structure of their needs as a result of the "elderly population" aging.

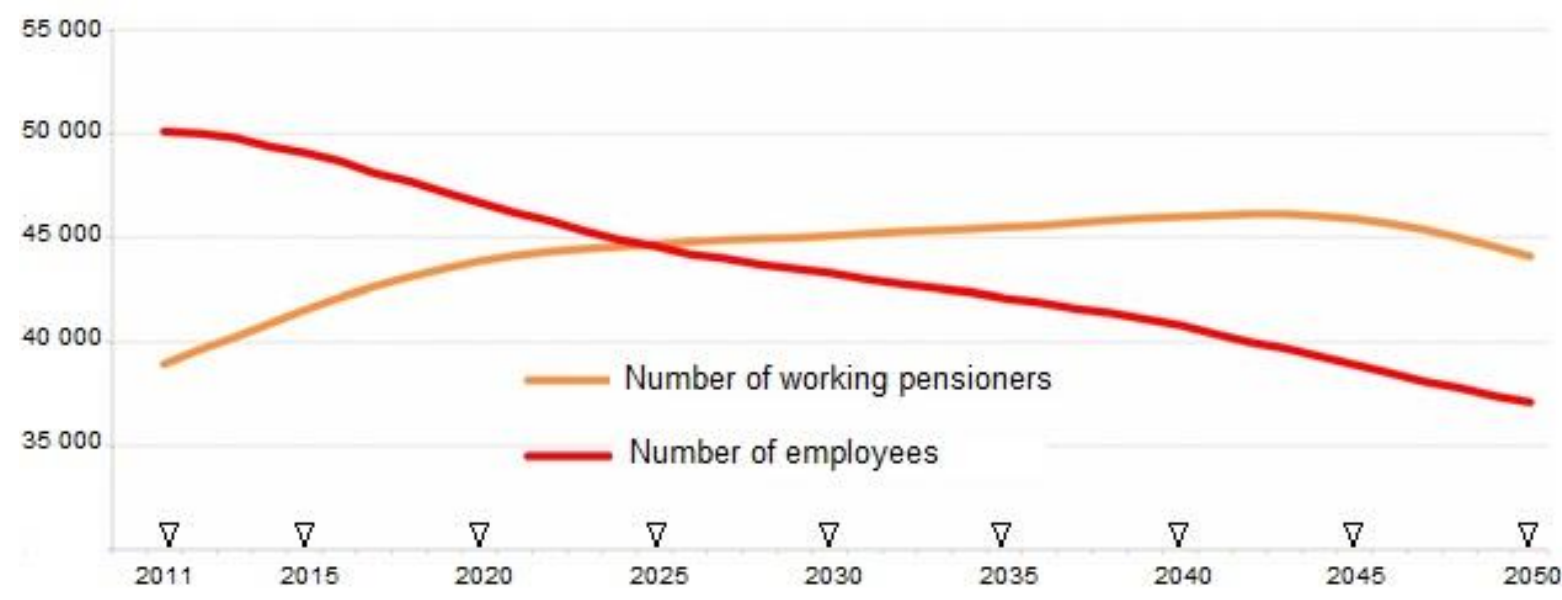

Fig 5 - Demographic and labor trends of the RF

Source: (Yakushev, 2012) 
In addition, the expected reduction in the death rate in men in senior working age groups will lead to an additional increase in the number of pensioners. According to the forecasts of the Pension Fund of the Russian Federation, a number of pensioners will exceed the number of employees in 2030-s (Figure 5). If the conditions and norms of the pension legislation are unchanged, maintaining the replacement rate at the present level will be impossible. At the same time, the number of pensioners in the Russian Federation will be growing drastically until the 2040s.

This indicates that the prospects for the domestic pension system are more likely to be negative and seem to imbalance the entire financial system, but domestic government estimates are overly optimistic. (Prigoda, 2015, p. 286)

The RF pension system requires the development of special tools for investing in pension savings, while inflation-neutral pension infrastructure bonds can become the most promising ones. Their profitability is self-balancing as a function of inflation expectations and the targeted zone on the stock market line (market risk) where the target zone is secured by infrastructure project risks and partial state guarantees. Development of such a tool will allow preserving and expanding the window of opportunities the RF government to solve common economic problems by monetary methods and at the same time to protect pension contributions of citizens.

Already in the first decade of 2000 , at the dawn of the formation of the RF contributory pension system, the key problem of pension reserves became obvious: lack of effective tools for their formation. The existing public debt does not meet the requirements of the moment. It is not quite profitable, because it does not cover the inflation, but at the same time the uses of the funds placed in it, such as coverage of the budget deficit, financing social, defense and other programs, smoothing fluctuations in the receipt of tax payments to the budget, form an additional debt, while the use of government bonds should be aimed at attracting and forming funds of a contributory pension system that ensure the growth of the Gross Domestic|Product. The issue of government securities should generate financial resources directed toward financing the so-called "development budget". We need state-owned securities of an innovative nature, but not state debts. Unfortunately, up to the present time, there are no government securities that solve this problem.

In our opinion, one of the most promising tools is an infrastructure bond. This tool has been wide, although quite recently, introduced in the business practice of foreign countries and in some cases it is actively used in the framework of pension systems.

Thus, aggregate estimates show that the share of infrastructure projects in the portfolio of Western pension funds is $10-23 \%$ of the value of assets and there is a steady increase in the share of funds invested by pension funds in infrastructure projects. At the same time, the volume of investments has increased by 30 times for five years.

In Australia, the main issuer of infrastructure bonds is the government. The turnover of infrastructural bonds is legally limited by a clearly marked list of objects that are considered infrastructural.

In India, there are two classes of bonds, one of which is tax-saving, as an investor in infrastructure bonds receives a tax credit on income tax. Savings are up to $20 \%$ of the investment amount.

The Chinese government has a great experience in shaping supply and demand in the bond market in the construction of railways through infrastructure bonds issued by the Construction Bank of China. Up to $70 \%$ of the railway infrastructure was financed by this tool.

In general, there are the following features compared to traditional corporate bonds in the international practice of issuing and trading infrastructure bonds:

- targeted use of funds obtained from the placement to implement long-term investment infrastructure projects (roads and railways, ports, airports, power lines, pipelines and oil, and gas pipelines);

- the issue of infrastructure bonds, mainly within the framework of the implementation of concession agreements between the state or local authorities and the concessionaire company that acts as the issuer of the bonds; 
- the main investors in infrastructure bonds are institutional (pension funds, insurance companies) and other conservative investors;

- a long-term period of circulation of infrastructure bonds, tied to the period of construction (reconstruction) of an infrastructure facility and to the period of its operation (on average 15-25 years);

- providing the bond issue with government guarantees, risk insurance, bank guarantees, and guarantees, as well as other security guarantees.

Thus, infrastructure bonds are one of the most dynamic instruments of the stock market and they are increasingly finding the application. All this combined with the underdevelopment of the domestic debt segment, the lack of credit and investment tools will serve as a stimulus for the development of the domestic market of infrastructure bonds.

\section{CONCLUSION}

Modern society is aging, and that leads to an increased burden on pension systems. Culturological changes occur implicitly, automatically and spontaneously - the value of an atomic family is reducing, the value of children is becoming higher than the value of adults. The institutions of marriage, inheritance, and even religion deteriorate and are adapted.

At the same time, the more rigid framework of economic models should be reconsidered in a directional way - spontaneous development of economic processes is dangerous, as was proved by the great American Depression. Thus, there is already a consensus that the economic world community needs to review many basic economic models, modernize institutions, especially pension ones since it is the latter that ensure the existence of a rapidly expanding class of pensioners and are at the center of global demographic shift processes.

In turn, the Russian pension system needs a change in the investment paradigm for achieving qualitatively new levels of efficiency in the use of accumulated resources, which consists in overcoming equalizing tendencies in the pension system, increasing its motivational potential, individualizing pension provision, and increasing profitability while reducing risks. These directions can be achieved with simultaneous expansion of the market investment capacity, allocation of specialized tools for the pension assets formation and changing approaches to the formation of longterm investment portfolios.

\section{WORKS CITED}

European Commision. (2015). The 2015 Ageing Report - Economic and budgetary projections for the 28 EU Member States (2013-2060). European Economy(3), 23.

Gokhale, J., \& Smetters, K. (2006). Fiscal and Generational Imbalances: An Update. In J. Poterba, NBER book Tax Policy and the Economy (Vol. 20, pp. 193-223). The MIT Press. Retrieved from The National Bureau of Economic Research.

Mintrud Rossii. (2012, Aug 24). Proyekt Strategii razvitiya pensionnoy sistemy Rossiyskoy Federatsii do 2030 goda. Retrieved from Ministry of Labor and Social Protection of the Russian Federation: https://rosmintrud.ru/uploads/magic/ru-RU/0e0735fb-1500961892.doc

opensii.info. (2010). Какое количество пенсионеров в России на 2016 год? Retrieved from O pensii: http://55-60.ru/pensija/kolichestvo-pensionerov-v-rossii.html

Prigoda, L. (2015). Osnovnyye napravleniya modernizatsii rossiyskoy ekonomiki. Mezhdunarodnyy ekonomicheskiy simpozium - 2015 (p. 634). St. Petersburg: St. Petersburg State University.

UN. (2011). World Population Prospects: The 2010 Revision, Volume II: Demographic Profiles. New York: United Nations, Department of Economic and Social Affairs, Population Division. Retrieved from https://dl.vecnet.org/files/xs55mc11m

Yakushev, E. (2012). The results of modeling the parameters of the pension system of the Russian Federation: contributory part of labor pension. European Pension Fund. Moscow: National Association of Non-State Pension Funds. 
Received for publication: 26.03.2018

Revision received: $\quad 11.09 .2018$

Accepted for publication: 27.12.2018

\section{How to cite this article?}

Style - APA Sixth Edition:

Kuizheva, S., \& Prigoda, L. (2019, January 15). Modern Trends in Demographic Development of Society: Financial Aspect. (Z. Čekerevac, Ed.) MEST Journal, 7(1), 41-47. doi:10.12709/mest.07.07.01.06

Style - Chicago Sixteenth Edition:

Kuizheva, Saida, and Lyudmila Prigoda. 2019. "Modern Trends in Demographic Development of Society: Financial Aspect." Edited by Zoran Čekerevac. MEST Journal (MESTE) 7 (1): 41-47. doi:10.12709/mest.07.07.01.06.

Style - GOST Name Sort:

Kuizheva Saida and Prigoda Lyudmila Modern Trends in Demographic Development of Society: Financial Aspect [Journal] // MEST Journal / ed. Čekerevac Zoran. - Belgrade - Toronto : MESTE, January 15, 2019. - 1 : Vol. 7. - pp. 41-47. doi:10.12709/mest.07.07.01.06

Style - Harvard Anglia:

Kuizheva, S. \& Prigoda, L., 2019. Modern Trends in Demographic Development of Society: Financial Aspect. MEST Journal, 15 January, 7(1), pp. 41-47.

Style - ISO 690 Numerical Reference:

Modern Trends in Demographic Development of Society: Financial Aspect. Kuizheva, Saida and Prigoda, Lyudmila. [ed.] Zoran Čekerevac. 1, Belgrade - Toronto : MESTE, January 15, 2019, MEST Journal, Vol. 7, pp. 41-47. 